\title{
DESIGN AND FABRICATION OF SOLAR TUNNEL DRYER FOR COPRA APPLICATION
}

\author{
P.M. Venkatesh', M. Kannan', A.R Vijay Babu' ${ }^{3}$, N. Bharath Kumar ${ }^{4}$ \\ ${ }^{1}$ Department of Electrical and Electronics Engineering, Vignan Foundation for Science Technology and Research, \\ Guntur, India, \\ ${ }^{2}$ Department of Mechanical Engineering,Jayalakshmi Institute of Technology, Thoppur, Salem, India \\ ${ }^{3}$ Department of Electrical and Electronics Engineering, Vignan Foundation for Science Technology and Research, \\ Guntur, India, \\ ${ }^{4}$ Department of Electrical and Electronics Engineering, Vignan Foundation for Science Technology and Research, \\ Guntur, India, \\ '202vijay@gmail.com, ${ }^{1}$ kannanpsg96@gmail.com
}

\begin{abstract}
A semi-cylindrical forced convection type solar tunnel dryer (STD) was designed and commissioned at M/s Miraj Products Pvt. Ltd., Nathdwara for drying processed tobacco. Essentially it is based on the mixed mode with direct and indirect type of heating mechanism i.e. the heated air from different solar flat plate collectors is passed through drying cabinet. At the same time, the drying cabinet absorbs solar energy directly through the transparent walls and roofs. It consists of $16 \times 3.75 \mathrm{~m}^{2}$ area, tunnel equipped with 12 solar flat plate collectors of $2 \mathrm{~m}^{2}$ each propelled with 2 exhaust fans of $1 \mathrm{~kW}$ capacity placed on both ends of the tunnel. The dryer was tested at no-load and full-load conditions. During no-load, without flat plate collectors, temperatures inside the dryer were about $18-20^{\circ} \mathrm{C}$ higher than the ambient temperature during summer day-light, where as in no-load with flat plate collectors, it was about $30^{\circ} \mathrm{C}$ higher than the ambient temperature. A batch of processed tobacco of $500 \mathrm{~kg}$ with an initial moisture content $138 \%$ d.b. were successfully dried in full load condition to have final moisture content of about $8.7 \%$ d.b. in $8 \mathrm{~h}$. It has been observed that STD has many other advantages i.e. getting rid of toxicant gas to labours during opening drying due to lime presence in material, avoidance of product expose to fly contamination and dust concentrations etc.
\end{abstract}

Keywords: Solar tunnel dryer (STD), natural convection, forced convection, mixed mode.

\section{Introduction}

Solar drying is a continuous process where moisture content, air and product temperature change simultaneously along with the two basic inputs to the systems: the solar insolation and inlet air at ambient temperature. The drying rate is affected by ambient climatic conditions. This includes temperatures, relative humidity, sunshine hours, solar insolation, wind velocity, frequency and duration of rain showers during the drying period etc. (Sevda, 2003). A solar tunnel dryer is essentially a poly house having tunnel like framed structure covered with ultraviolet (UV)-stabilized polythene sheet, where agricultural and industrial products could be dried under at least partially control environment, in which loading and unloading is quite easy (Sevda, 2007). A mixed-mode solar dryer allows the heated air from a separate solar collector to pass through a grain bed, and at the same time, the drying cabinet also absorbs solar energy directly through the transparent walls and roof. The performance evaluation of such a dryer revealed that the temperatures inside the dryer and solar collector were much higher than the ambient temperature during most time of the day light (Bukola, Bolaji and Ayoola, 2008).

\section{Design of solar tunnel dryer}

The mixed-mode type forced convection solar tunnel dryer shown in Fig.1 was designed to dry $0.5 \mathrm{t}$ of processed tobacco from $138 \%$ d.b. to $11 \%$ d.b. moisture content with flat plate air heating collectors, a tunnel drying unit and 
blowers to provide the required air flow rate over the product. The design parameters were decided on the basis of amount of moisture to be removed, specific gravity of material, and flow rate required for removing moisture in stipulated time.

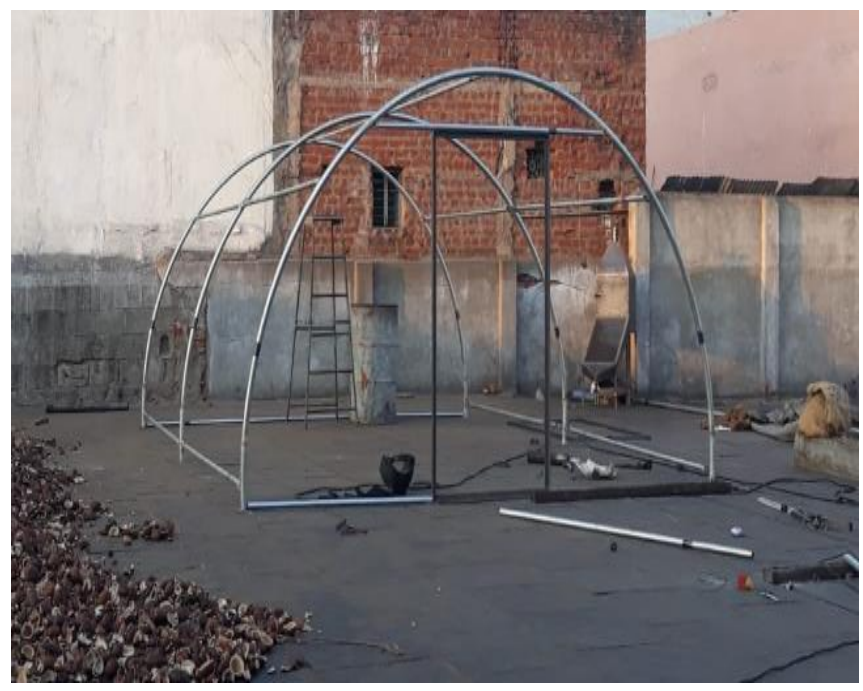

Fig.1. Frame work of solar Tunnel dryer

The drying unit was covered with transparent UV stabilized semi-transparent polythene sheet of $2 \times 10^{-4} \mathrm{~m}$ thickness. Low cost materials possessing high rigidity, long life and superior thermal characteristics were used for construction of floor, super structure and solar collectors. Cement concrete floor was painted black for better absorption of solar radiation. 5 $\mathrm{cm}$ thick glass wool insulation was provided to reduce heat loss through the floor. It was based on the theoretical calculation for critical insulation thickness for this dryer. The orientation of solar tunnel dryer was in east-west direction, so the sun covers the south side and the north side of the dryer act as an absorber. The north wall has a metallic cover of height of $1.5 \mathrm{~m}$ and glass wool sandwich in metallic cover for insulation. The products to be dried were placed in a thin layer on a stainless steel wire screen trays that are sliding on ball bearing for easy loading. Efforts were made for continuous and automatic loading of material inside the dryer. Various strategies for increasing work efficiency of system were developed during test of the system in actual use, like the loading of product in layer of constant thickness by the hopper, below the hopper the trays moves with constant speed by the motor, and trays can easily loaded in dryer by sliding on the ball bearing on rail from outside of the dryer.

The salient features of the solar tunnel dryer commissioned at the Sri Jayasakthi Edible Oil Pvt. Ltd., Salem were as follows, semicylindrical poly house having base area of $8 \mathrm{~m} \times 3$ $\mathrm{m}$ and with maximum ceiling height of $2.5 \mathrm{~m}$, the metallic frame structure covered with polythene sheet. Incoming air through bottom opening of $100 \mathrm{~mm}$ and turbo fan as been placed on the top surfaces to provide the fresh air continuously to the dryer. The dryer was loaded with 1.5 tonne capacity of copra and initial moisture content of copra deducted as $53.2 \%$. at the start of experiment. The uniform speed of inlet velocity varied between $1.5 \mathrm{~m} / \mathrm{s}$ to $3 \mathrm{~m} / \mathrm{s}$. Fig. 2 shows the fully Loaded copra on the solar tunnel dryer.

\section{Experimental analysis of solar tunnel}

The analysis of solar tunnel for four consecutive days is tabulated in Table- 1 to Table-4.

Table .1 Analysis of solar tunnel on day-1

\begin{tabular}{|c|c|c|c|c|c|}
\hline $\begin{array}{c}\text { TIME } \\
(\mathrm{Hr})\end{array}$ & $\begin{array}{c}\text { Moisture } \\
(\%)\end{array}$ & $\begin{array}{c}\text { Tamb } \\
\left({ }^{\circ} \mathrm{c}\right)\end{array}$ & $\begin{array}{c}\text { Tdryer } \\
\left({ }^{\circ} \mathrm{c}\right)\end{array}$ & Humidity & $\begin{array}{c}\text { Solar } \\
\text { Constant }\end{array}$ \\
\hline $9 \mathrm{AM}$ & 55.68 & 28.5 & 38.5 & 51 & 362 \\
\hline $10 \mathrm{AM}$ & 53.24 & 29 & 41.5 & 53 & 436 \\
\hline $11 \mathrm{AM}$ & 51.72 & 31.2 & 45.7 & 56 & 512 \\
\hline $12 \mathrm{NOON}$ & 50.06 & 33 & 49.2 & 59 & 635 \\
\hline $1 \mathrm{PM}$ & 48.46 & 33.5 & 52.7 & 61 & 729 \\
\hline
\end{tabular}




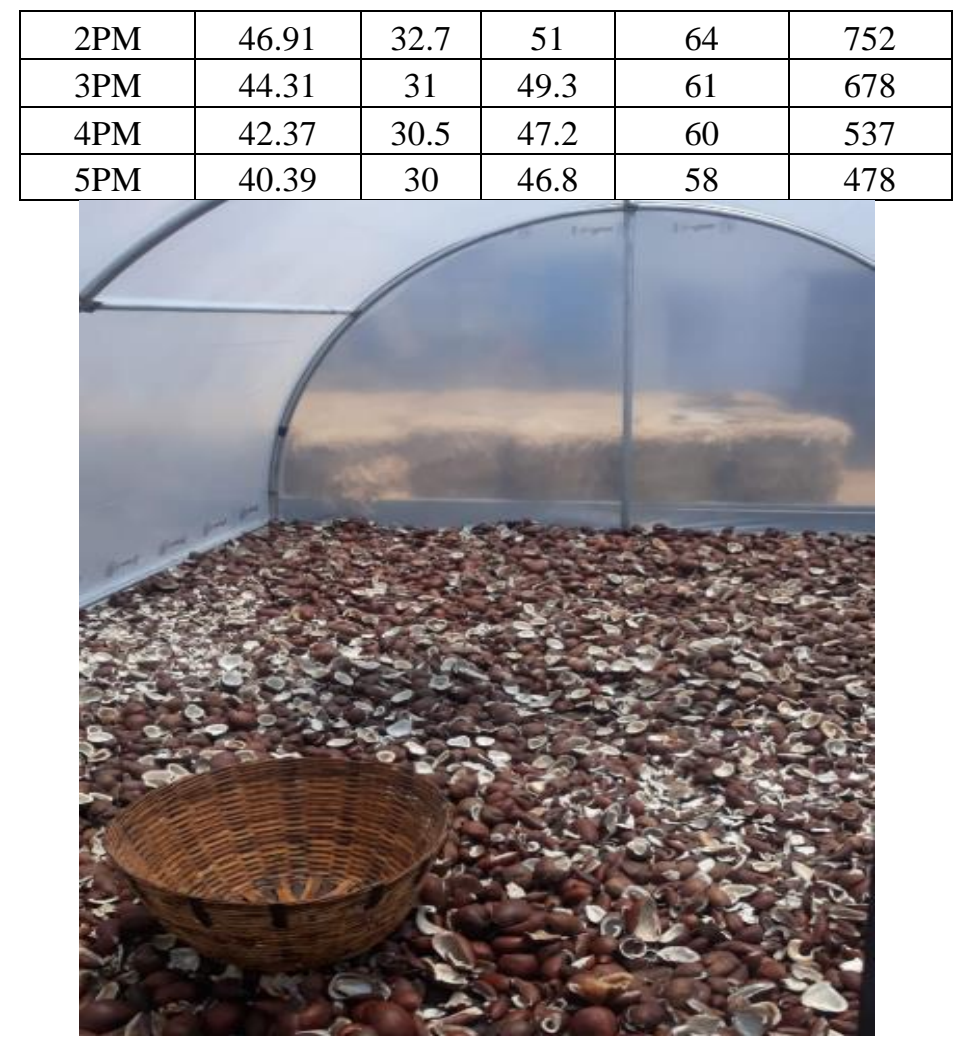

Fig.2. Fully Loaded copra on the solar tunnel dryer

Table .2 Analysis of solar tunnel on day-2

\begin{tabular}{|c|c|c|c|c|c|}
\hline $\begin{array}{c}\text { TIME } \\
(\mathrm{Hr})\end{array}$ & $\begin{array}{c}\text { Moisture } \\
(\%)\end{array}$ & $\begin{array}{c}\text { Tamb } \\
\left({ }^{\mathrm{c}}\right)\end{array}$ & $\begin{array}{c}\text { Tdryer } \\
\left({ }^{\circ} \mathrm{c}\right)\end{array}$ & Humidity & $\begin{array}{c}\text { Solar } \\
\text { Constant }\end{array}$ \\
\hline 9AM & 36.81 & 28 & 38.2 & 53 & 346 \\
\hline 10AM & 34.12 & 27.6 & 40.1 & 55 & 418 \\
\hline 11AM & 32.37 & 29 & 41.4 & 58 & 497 \\
\hline 12NOON & 30.45 & 30.8 & 46.2 & 63 & 587 \\
\hline 1PM & 28.97 & 31.5 & 47 & 65 & 693 \\
\hline 2PM & 26.37 & 32 & 50.9 & 68 & 712 \\
\hline 3PM & 24.29 & 31.2 & 50.1 & 64 & 643 \\
\hline 4PM & 22.17 & 30.6 & 48.7 & 62 & 502 \\
\hline 5PM & 20.13 & 30.2 & 46.9 & 59 & 451 \\
\hline
\end{tabular}

Table .3 Analysis of solar tunnel on day-3

\begin{tabular}{|c|c|c|c|c|c|}
\hline $\begin{array}{c}\text { TIME } \\
(\mathrm{Hr})\end{array}$ & $\begin{array}{c}\text { Moisture } \\
(\%)\end{array}$ & $\begin{array}{c}\text { Tamb } \\
\left({ }^{\mathrm{c}} \mathrm{c}\right)\end{array}$ & $\begin{array}{c}\text { Tdryer } \\
\left({ }^{\mathrm{c}} \mathrm{c}\right)\end{array}$ & Humidity & $\begin{array}{c}\text { Solar } \\
\text { Constant }\end{array}$ \\
\hline 9AM & 17.29 & 29.1 & 40.2 & 52 & 353 \\
\hline 10AM & 16.14 & 30.7 & 42.8 & 55 & 425 \\
\hline 11AM & 15.31 & 31 & 45.2 & 57 & 504 \\
\hline 12NOON & 14.98 & 32.4 & 47.9 & 60 & 627 \\
\hline 1PM & 13.21 & 33.6 & 51.3 & 62 & 709 \\
\hline 2PM & 12.98 & 34 & 55.2 & 65 & 721 \\
\hline 3PM & 11.71 & 32.7 & 54.3 & 61 & 667 \\
\hline 4PM & 10.35 & 32.1 & 51.4 & 59 & 503 \\
\hline 5PM & 9.65 & 31.5 & 49.8 & 56 & 452 \\
\hline
\end{tabular}

Table .4 Analysis of solar tunnel on day-4 


\begin{tabular}{|c|c|c|c|c|c|}
\hline $\begin{array}{c}\text { TIME } \\
(\mathrm{Hr})\end{array}$ & $\begin{array}{c}\text { Moisture } \\
(\%)\end{array}$ & $\begin{array}{c}\text { Tamb } \\
\left({ }^{\mathrm{c}} \mathrm{c}\right)\end{array}$ & $\begin{array}{c}\text { Tdryer } \\
\left({ }^{\circ} \mathrm{c}\right)\end{array}$ & Humidity & $\begin{array}{c}\text { Solar } \\
\text { Constant }\end{array}$ \\
\hline 9AM & 7.86 & 28.1 & 38.6 & 52 & 342 \\
\hline 10AM & 6.97 & 28.7 & 39.1 & 54 & 407 \\
\hline 11AM & 6.57 & 29.4 & 41.6 & 57 & 478 \\
\hline 12NOON & 6.41 & 31.3 & 44 & 59 & 557 \\
\hline 1PM & 6.38 & 32.3 & 48.6 & 63 & 663 \\
\hline 2PM & 6.30 & 33.4 & 53 & 68 & 714 \\
\hline 3PM & 6.24 & 31.64 & 51 & 65 & 621 \\
\hline 4PM & 6.20 & 30.9 & 49.2 & 63 & 497 \\
\hline 5PM & 6.15 & 30.4 & 48 & 61 & 447 \\
\hline
\end{tabular}

\section{Results \& discussions}

\section{MOISTURE(\%)}

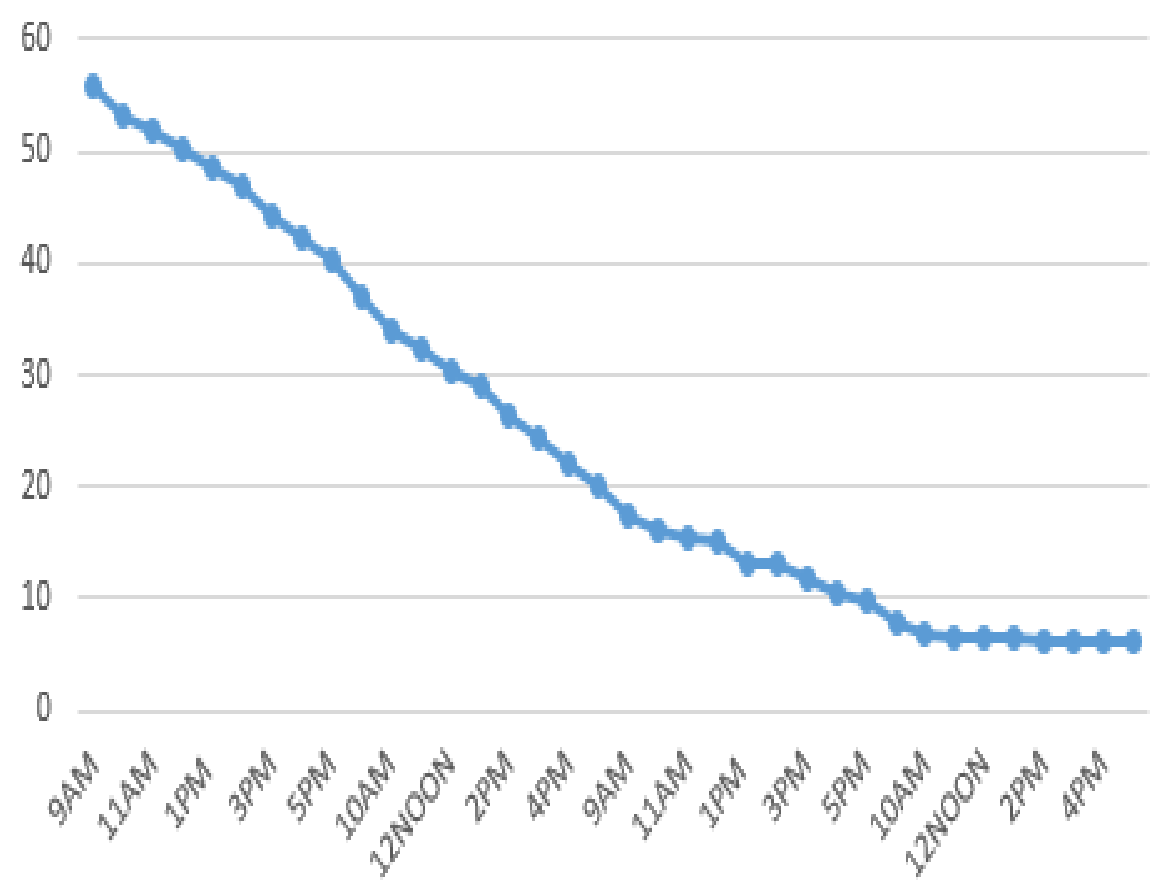

Fig.3. Time vs Moisture content

Fig.3 shows that the moisture content varied with the time. The Initial moisture content at the copra is $55.6 \%$ and its end to final moisture content of $6.15 \%$. The Maimum moisture level reduced during the initial three days compared with final day and moisture remain constant after the maximum reduction of water from it. 


\section{Tamb VS Tdryer}
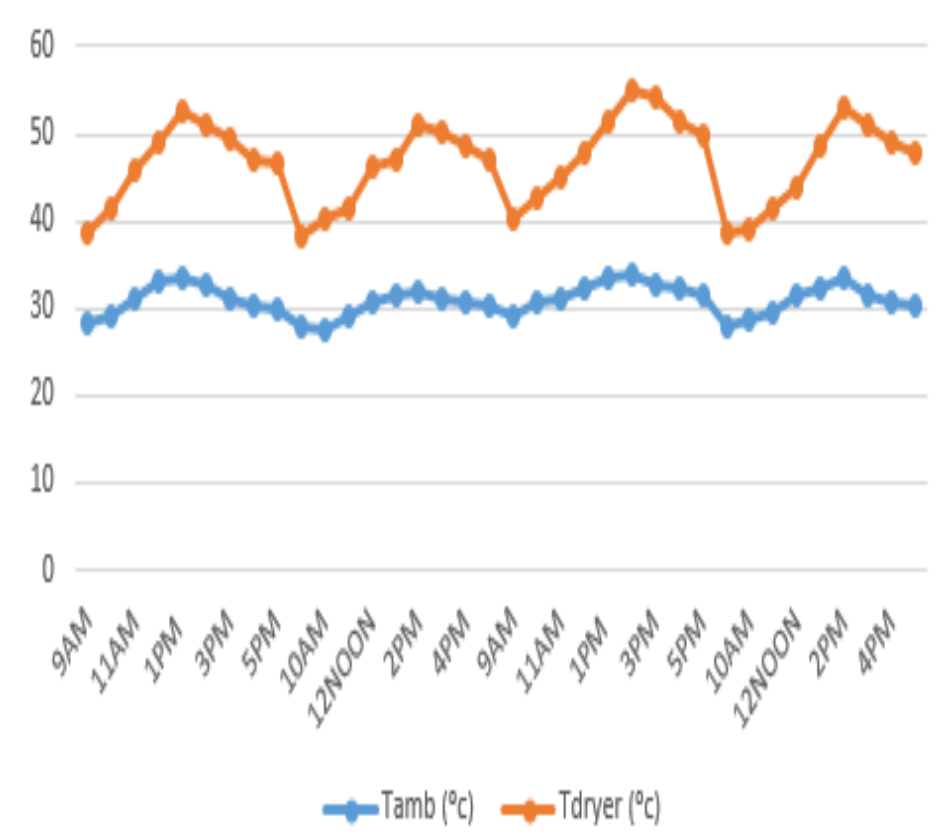

Fig.4. Time vs Ambient temperature and Dryer temperature

Fig.4 shows that the variation of ambient temperature and dryer temperature. The maximum ambient temperature of $34^{\circ} \mathrm{Cattained}$ during $2 \mathrm{pm}$ and maximum dryer temperature of $55.2^{\circ} \mathrm{C}$. By the comparison of ambient temperature and dryer temperature there are $15^{\circ} \mathrm{C}$ to $20^{\circ} \mathrm{C}$ temperature varies.

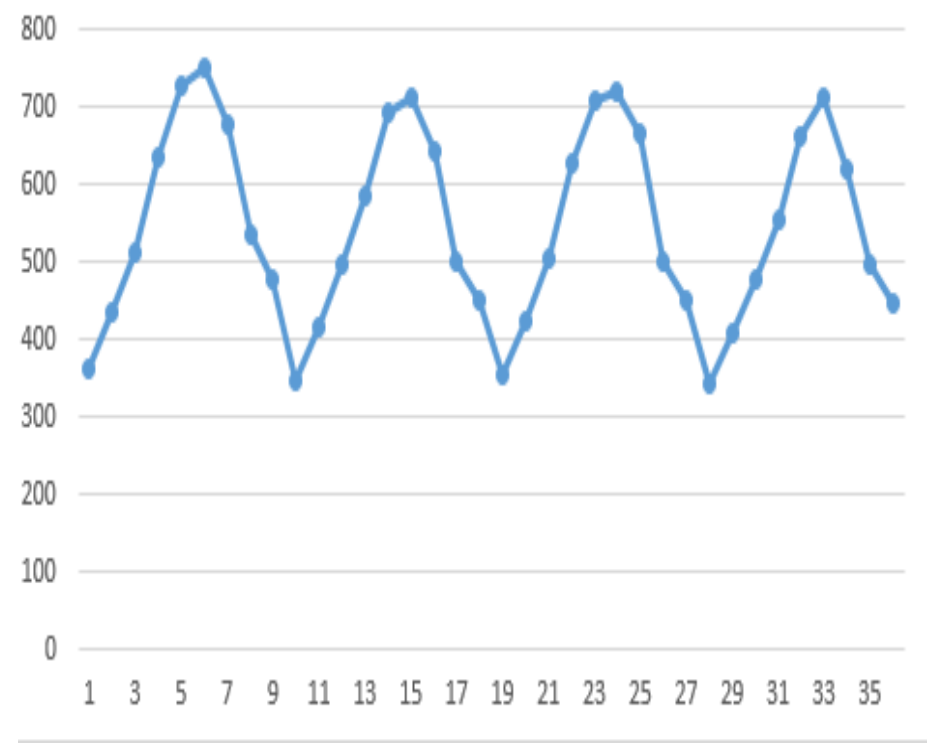

Fig.5. Time vs Solar constant

Fig.5 shows that the variation of time and solar constant. The maximum solar constant of Copyright $\odot$ Authors
$752 \mathrm{~W} / \mathrm{m} 2$ attained during the peak hour. Based on the maximum solar constant the temperature 
also increased and drying time for copra is decreased. The quality of sun dried and solar tunnel dried copra is tabulated in Table. 5 and Table.6 respectively.

Table .5 Sun Dried Copra Quality

\begin{tabular}{|l|c|}
\hline \multicolumn{1}{|c|}{ CHARACTERISTICS } & CONTENTS \\
\hline IMPURITIES $\%$ & 9 \\
\hline MOULDY CUPS $\%$ & 25 \\
\hline BLACK CUPS $\%$ & 2 \\
\hline WRINKLED CUPS\% & 2 \\
\hline MOISTURE CONTENT\% & 7 \\
\hline PEROXIDE VALUE & 1 \\
\hline FFA & 0.8 \\
\hline SPECIFIC GRAVITY & 0.93 \\
\hline IODINE VALUE & 8.7 \\
\hline
\end{tabular}

Table .6 Solar Tunnel Dried Copra Quality

\begin{tabular}{|l|c|}
\hline CHARACTERISTICS & CONTENTS \\
\hline IMPURITIES\% & 6 \\
\hline MOULDY CUPS\% & 11 \\
\hline BLACK CUPS\% & 3 \\
\hline WRINKLED CUPS\% & 2 \\
\hline MOISTURE CONTENT\% & 6.4 \\
\hline PEROXIDE VALUE & 0.5 \\
\hline FFA & 2 \\
\hline SPECIFIC GRAVITY & 0.9 \\
\hline IODINE VALUE & 8 \\
\hline
\end{tabular}

\section{Conclusions}

From the test carried out for copra, the following conclusions were made. The solar dryer can raise the ambient air temperature to a considerable high value for increasing the drying rate of agricultural crops. The reduction in drying time occurs by increasing air flow rate. The food items are also well protected in the solar dryer than in the open sun, thus minimizing the case of pest and insect attack and also contamination. Although the dryer was used to dry copra, grapes, onion but it can be used to dry other crops etc. The drying time of copra reduced compared with natural drying method.

\section{Refrences}

Copyright $\odot$ Authors

[1] M.A.Boda and C.V.Papade, "Design \& Development of Indirect Type Solar Dryer with Energy Storing Material". An International Journal of Innovative Research in Advanced Engineering, 1(12), 2014, 109-114

[2] Bukola, O., Bolaji and Ayoola P. Olalusi. 2008. Performance evaluation of a mixedmode solar dryer. AU J.T. 11(4): 225-231.

[3] Çakmak, Gülşah, and CengizYıldız, The drying kinetics of seeded grape in solar dryer with PCM-based solar integrated collector, Food and bio products processing, 89(2), 2011, 103-108. 
[4] D.K.Rabha, P.Muthukumar, C.Somayaji, Experimental investigation of thin layer drying kinetics of ghost chilli pepper (Capsicum Chinense Jacq.) dried in a forced convection solar tunnel dryer, Renewable Energy, 105 (2017), 583589.

[5] Sevda M. S., N. S. Rathore, and P. Singh. 2004. Techno-economics of solar tunnel dryer-A case study. Journal of Agricultural Engineering, 41 (3): 13-17.

[6] Mohamed A. Eltawil, Mostafa M. Azam, Abdulrahman O. Alghannam, Energy analysis of hybrid solar tunnel dryer with PV system and solar collector for drying mint (MenthaViridis), Journal of Cleaner Production, 181 (2018), 352-364.

[7] Shriramulu, Development of Solar Tunnel Dryer for Drying of Silkworm Pupae,Univ. of Agricultural Sciences GKVK, Bengaluru, 2017.

[8] Yusto Yustas, Cuthbert Z. M. Kimambo, A reliable performance evaluation procedure for natural convection mixed mode solar dryer, International Journal of Postharvest Technology and Innovation, 5 (2018).

[9] J. K. Chelanga, J K Tonui, Evaluation of Performance of a Solar Tunnel Crop Dryer in Drying of Two African Indigenous Vegetables (Aivs), Kabarak Journal of Research \& Innovation, 5 (2018).

[10] Rathore, N. S. 2004. Industrial application of solar tunnel dryer. IREDA News, January-March 2004. 